\title{
Fen Bilgisi Öğretmen Adaylarının Yoğuşma ve Yoğunlaşma Kavramlarına Yönelik
} Görüşlerinin Belirlenmesi

\section{Hakan Şevki AYVACI* ve Bahar MURADOĞLU**}

Öz: Bu çalışmada fen bilgisi öğretmen adaylarının yoğuşma ve yoğunlaşma kavramlarına yönelik görüşlerinin tespit edilmesi ve buna bağlı olarak kavram yanılgısı ve yanlış anlama düzeylerinin belirlenmesi amaçlanmıştır. Yoğuşma ve yoğunlaşma kavramlarına yönelik fen bilgisi öğretmen adaylarının görüşlerinin derinlemesine incelenmesi için çalışmada, örnek olay yöntemi kullanılmıştır. Çalışma 2020-2021 eğitim-öğretim yılı güz döneminde Karadeniz Bölgesi’nde yer alan bir devlet üniversitesinde "Fen Bilgisi Öğretmenliği” programında öğrenim gören 37 kadın ve 5 erkek olmak üzere toplam 42 fen bilgisi öğretmen adayı ile yürütülmüştür. Araştırmanın verileri Fizik-III dersi kapsamında toplanmıştır. Fen bilgisi öğretmen adaylarının yoğuşma ve yoğunlaşma kavramlarına yönelik görüşlerinin belirlenmesi için veri toplama metodu olarak açık uçlu anket tercih edilmiştir. Araştırmacı tarafından uzman görüşü alınarak hazırlanan bu form, yoğuşma ve yoğunlaşmanın ne olduğu, örneklerinin neler olduğu ve varsa bu iki kavramın benzerlik ve farklılıklarının neler olduğuna ilişkin toplamda 5 sorudan oluşmaktadır. Araştırma kapsamında gerekli izinler alınarak, öğretmen adaylarının gönüllü olmalarına dikkat edilmiş ve pandemi sürecinden ötürü veriler e-posta sistemi üzerinden toplanmıştır. Çalışmadan elde edilen verilerin analizinde betimsel analizden faydalanılmıştır. Verilerin analizi sonucunda genel olarak öğretmen adaylarının yoğuşma ve yoğunlaşma kavramlarına ilişkin yanılgılara sahip oldukları ve kavramları birbirlerinin yerine kullanarak ayrım yapamadıkları görülmüştür. Nedeninin ise "Fen Bilimleri Dersi Öğretim Programı”nda ve ders kitaplarında bu kavramların birbiri yerine kullanıldığından kaynaklanabileceği düşünülmektedir. Araştırma sonuçlarına dayanarak fen bilgisi öğretmen adaylarının kavram yanılgılarının giderilebilmesi amacıyla farklı öğretim yöntem ve tekniklerinin kullanılabileceği önerilmektedir.

\footnotetext{
* Prof. Dr., Trabzon Üniversitesi, Eğitim Fakültesi, Matematik ve Fen Bilimleri Eğitimi Bölümü, Email: hsayvaci@gmail.com, 0000-0002-3181-3923

** Doktora Öğrencisi, Trabzon Üniversitesi, Lisansüstü Eğitim Enstitüsü, Email: bahar.muradoglu@gmail.com, Orcid No: 0000-0003-1233-8458.

*** Bu araştırma için Trabzon Üniversitesi Sosyal ve Beşeri Bilimler Etik Kurulu Başkanlığında (30/11/2020 tarih ve 81614018-000-E.518 sayısı) etik izni alınmıştır.
} 
Anahtar Kelimeler: Yoğuşma, Yoğunlaşma, Fen bilgisi öğretmen adayı

\section{Determining the Opinions of Science Teacher Candidates about Condensation and}

\section{Concentration}

Abstract: In this study, it was aimed to determine the opinions of science teacher candidates about the concepts of condensation and concentration, and accordingly to determine the level of misconception and misunderstanding. The case study method was used in the study in order to determine the opinions of science teacher candidates about condensation and concentration concepts in depth. The study was conducted with a total of 42 science teacher candidates who were studying in the "Science Teaching" program in a state university in the Black Sea Region in the fall semester of the 2020-2021 academic year. The research data were collected within the scope of Physics-III course. An open-ended questionnaire was preferred as a data collection method to determine the opinions of science teacher candidates about condensation and concentration concepts. This form, which was prepared by the researcher through taking the expert's opinion, consists of a total of 5 questions about what the condensation and concentration are, what their examples are, and what are the similarities and differences of these two concepts, if any. Within the scope of the research, the necessary permissions were obtained, attention was paid to the volunteering of the teacher candidates and the data were collected via e-mail system due to the pandemic process. Descriptive analysis was used in the analysis of the data obtained from the study. As a result of the analysis of the data, it was seen that the teacher candidates generally had misconceptions about the concepts of condensation and concentration and could not distinguish the concepts by using interchangeably. The reason is thought to be that these concepts are used interchangeably in the science teaching programs and textbooks. Based on the results of the research, it is suggested that different teaching methods and techniques can be used in order to eliminate the misconceptions of science teacher candidates.

Keywords: Condensation, Concentration, Science, Teacher candidate

\section{Giriş}

Bilim ve teknolojinin hızlı gelişimi ile günümüzde doğru bilgiye nasıl ulaşabileceğini bilen, sorgulayan, eleştirel düşünebilen, karar verme, yaratıcılık ve yenilikçilik gibi becerilere sahip fen okuryazarı bireyler yetiştirmek hedeflenmektedir (AAAS, 2015; MEB, 2018). Bu hedef doğrultusunda “Fen Bilimleri Dersi Öğretim Programı”nda, araştırma-sorgulamaya dayalı yaklaşım temel alınarak kavram öğretimi yapılması gerektiği üzerine odaklanılmıştır. 
Öğrencilerin bilişsel yapılarını, geçmiş bilgileri ile yeni bilgilerini ilişkilendirip başarılı bir öğrenme süreci gerçekleştirmeleri beklenmektedir (Coştu, 2002; Thomas M. Sherman ve Kurshan, 2005).

Zihinde oluşturulması nedeniyle soyut bir özelliğe sahip olan kavram kelimesi, fen eğitiminde farklı bilgi türlerinin arasında en önemlisi olarak görülmekte ve farklı şekillerde tanımlanmaktadır. Genel anlamda yaşantı sürecindeki deneyimlerimiz sonucunda iki veya daha fazla varlığı ortak özelliklerine göre bir arada gruplayıp diğer varlıklardan ayırt ederek zihnimizde bir düşünce biçimi olarak depolarız. Bu düşünce birimlerine kavram denilmektedir (Çepni, 2015; Janiuk, 1993; Ralph, Sexton, Wagner ve Gerlovic, 1998). Kavram öğreniminde öğrenciler daha önceden öğrendikleri kavramları kullanarak, önceki kavramlar ile yeni kavramlar arasında bağ kurmaktadırlar. Bu bağların yanlış kurulmasıyla konuların yanlış öğrenilmesi ve öğrenmenin niteliğinin düşmesi durumu ile karşılaşılmaktadır. Bunun nedeni ise öğrencilerin bazı kavramları anlamakta güçlük çekmeleri ile ilişkilendirilmekte olup bu kavramlara yönelik yanlış anlamalar gerçekleştirmeleridir. Eğitimin her aşamasında karşımıza çıkan birçok kavram yanılgısı durumu vardır (Coştu, 2002; Laçin-Şimşek, Öztuna-Kaplan, Çorapçıgil ve Mısır, 2018). Şüphesiz ezberci eğitimin sonucu olarak bu yanılgıların düzeltilmesinin de oldukça zor olduğu görülmektedir (Karaer, 2007).

Öğrencilerin kü̧̈ük yaşlarda kavramlara ilişkin doğru öğrenmeler gerçekleştirmeleri ileriki yaşlardaki etkin öğrenme deneyimlerine sahip olmaları için oldukça önemlidir (Bozkurt ve Çakır, 2016). Bu noktada en önemli görev fen bilgisi öğretmenlerine düşmektedir. Bu kavramların öğrenciler tarafından doğru anlaşlabilmesi için fen bilgisi öğretmen adayları öncelikle kendileri bu kavramları doğru anlamalıdırlar ki meslek yaşantılarında da öğrencilerinin anlamlı öğrenme firsatı sağlayabilsinler.

Fen eğitiminin en önemli basamaklarından biri olan kavramların öğrenimi, kavram yanılgıları, bu yanılgıların nedeni ve nasıl engellenebileceğine veya giderilebileceğine yönelik fen eğitiminde pek çok çalışma ile karşılaşılmaktadır. Bunun nedeni fen konularının yoğun bir şekilde kavramlar üzerinden açıklanmasıdır. Alan yazında yer alan bu kavramlardan birkaçı 1sısıcaklık (Aydoğan, Güneş ve Gülçiçek, 2003), kaynama-buharlaşma (Kirikkale ve Güllü, 2008), çözünürlük (Coştu, Ayas, Açıkkar ve Çalık, 2007), yoğuşma (Bar and Travis, 1991), hal değişimi (Osborne and Cosgrove, 1983), buharlaşma ve yoğunlaşma (Tytler, 2000), buharlaşma (Prain, Tytler and Peterson, 2009), buharlaşma-kaynama-yoğunlaşma (Coştu, 2002) gibidir.

İlgili literatür incelendiğinde, özellikle madde konusunda pek çok kavram yanılgısının varlığı söz konusu olduğundan öğrencilerin bu kavramları erken yaşlarda anlamakta güçlük 
çektikleri bu nedenle de ileriki yıllarda diğer konularda da ciddi kavrama sorunları yaşayabilecekleri ifade edilmektedir. Bu noktada öğretmen ve öğretmen adaylarının kavramsal anlama düzeylerinin de incelenmesi öğrencilerin bu kavramları anlamaları açısından önemlidir. $\mathrm{Bu}$ açıdan bakıldığında fen bilgisi öğretmenlerinin hizmet öncesi dönemde kavramlara yönelik görüşlerinin ne düzeyde olduğu da merak konusu olmuş ve bu çalışmada fen bilgisi öğretmen adaylarının yoğuşma ve yoğunlaşma kavramlarına yönelik görüşlerinin tespit edilmesi amaçlanmıştır.

Bu noktada alan yazında bu kavramların ayrımına yönelik sınırlı sayıda çalışmanın yürütüldüğü (Chinn, 1995) ve yüzeysel kaldığı görülmüsştür. Bu açıdan öğretmenlerin görüşleri alınıp akademik sonuçlar çıkarılmalı ve bu sonuçlara bağlı olarak da önerilerde bulunulması gereklidir. Bu kavramların öğrenciler tarafından doğru öğreniminin gerçekleşmesi açısından hizmet öncesi dönemde öğretmen adaylarının kavram yanılgıların var olup olmadığı tespit edilerek var ise nasıl giderilebileceği açısından diğer araştırmalara ışık tutacağı düşünülmektedir.

\section{Kavramsal Çerçeve}

Yoğuşma (condensation), bir sistemden ısının ayrılması sonucu buharın sıviya dönüşmesi şeklinde gerçekleşen bir eylem olarak tanımlanır. Bu, buhar, damlacıkların çekirdeklenmesini indüklemek için doyma sıcaklığının yeterince altında soğutulduğunda gerçekleşebilir (Gardner, 1963). Gerekli sıcaklık farkı sağlanmadığı ve uygun şartların

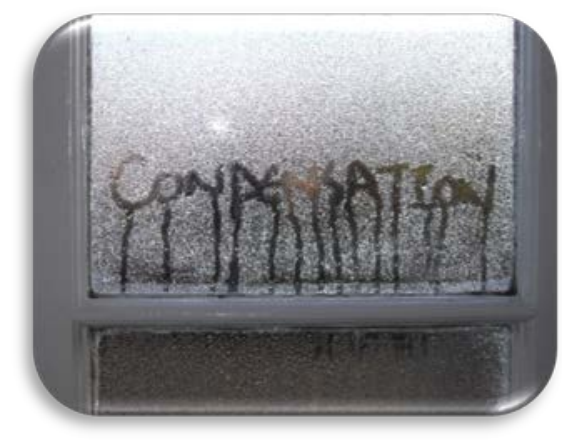

(üzerinde gazın yoğuşabileceği yüzeyin varlığı gibi) oluşmadığı sürece gerçekleşmesi mümkün olmamaktadır. Yürütülen işleme bağlı olarak madde buhar halinden yani gaz halinden damlacıklar haline yani sıvı hale evrilir. Dolayısıyla da yoğuşma bir hal değişim sürecidir (Chinn, 1995; Collier and Thome, 1994). Buharlaşma eyleminin tersi olarak tanımlanan yoğuşma eyleminde buhar halinde bulunan bulutun gerekli koşullara bağlı olarak damlacıklar şeklinde sıvı hale dönüşmesine örnek olarak genellikle su döngüsü sunulmaktadır. Zar şeklinde yoğuşma, damla şeklinde yoğuşma, yüzeye gerilimli yoğuşma, buğu yolu ile yoğuşma ve sis damlaları şeklinde yoğuşma olmak üzere beş türü bulunmaktadır (Stephen, 1988). 
Genellikle yoğunlaşma kavramı, nispeten düşük konsantrasyonlu çözeltiler için "seyreltik (dilute)" ve nispeten yüksek konsantrasyonlu çözeltiler için "konsantre (concentration) " gibi sıfatların kullanılmasıyla nitel bir şekilde tanımlanır. Yoğuşmadan etkilenebilir olan ve madde miktarına bağlı olarak değişiklik gösteren bir kavramsal bütünlüktür (Turner, 1972). Bir bileşenin bolluğunun bir karışımın toplam hacmine

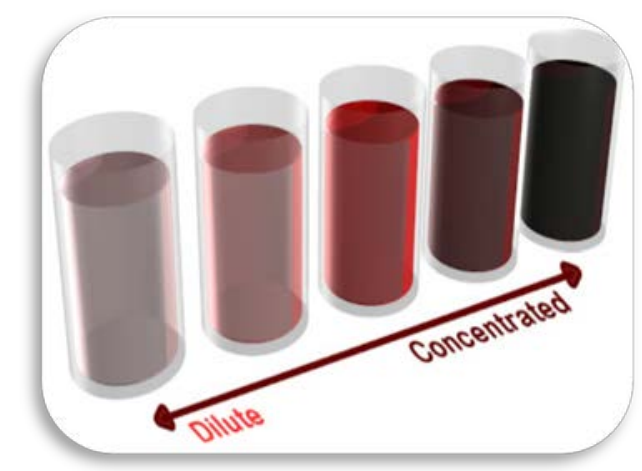
bölünmesi sonucu olan değerin artmasıdır. Yani birim hacimdeki madde miktarı özkütle veya yoğunluğun (density) artması durumudur. Hal değiştirme sürecinde yani yoğuşma durumunda da artış gösterir. Yoğunluğun artması için illa sıcaklığın azalması gerekmez. Cisim farklı yöntemler ile de sıkıştırıldığında veya saflaştırıldığında yoğunlaşma gerçekleşir (Chinn, 1995; Stephen, 1988). Örneğin; demire bir kuvvet uygulayarak dövdüğümüzde moleküller bir araya sıkışır böylece birim hacimdeki molekül miktarı artar ve yoğunlaşır. Suyu sıkılmış üzümü kaynattığımızda içerisinde su miktarı buharlaşır ve böylece yoğunluğu artar. Bu durumda da yoğunlaştı ifadesi kullanılır. Kütle konsantrasyonu, molar konsantrasyon, sayı konsantrasyonu ve hacim konsantrasyonu olmak üzere dört türü bulunmaktadır.

\section{Yöntem}

\section{Araştırmanın Deseni}

Yoğuşma ve yoğunlaşma kavramlarına yönelik fen bilgisi öğretmen adaylarının görüşlerinin derinlemesine incelenmesi için nitel araştırma yöntemine göre yürütülen çalışmada, örnek olay kullanılmıştır (Yıldırım ve Şimşek, 2018). Çalışmanın nitel araştırma yöntemine göre yürütülmesindeki amaç yoğuşma ve yoğunlaşma kavramlarına yönelik bilişsel yapılanmaların açığa çıkarılması ve belirlenen konuda derinlemesine bilgi elde etmektir. $\mathrm{Bu}$ yöntemde örneklem sayısı az tutulmaya çalışılır, sonuçların genellenmesi söz konusu değildir. Amaç konu hakkında detaylı bilgi elde etmektir (Çepni, 2014).

\section{Çalışma Grubu}

Çalışma, 2020-2021 eğitim-öğretim yılı güz döneminde Karadeniz Bölgesi’nde yer alan bir devlet üniversitesinde "Fen Bilgisi Öğretmenliği” programında öğrenim gören 37 kadın ve 5 erkek olmak üzere toplam 42 fen bilgisi öğretmen adayı ile yürütülmüştür. Araştırmanın verileri Fizik-III dersi kapsamında toplanmıştır. Araştırmada etik kurallar çerçevesinde 
katılımcı öğretmen adaylarının isimleri kullanılmamış ve Ö1, Ö2,.., Ö42 şeklinde kodlanmıştır. Çalışma grubunun cinsiyete göre dağılımı Tablo 1'de verilmiştir.

Tablo 1. Araştırmaya Katılan Fen Bilgisi Öğretmen Adaylarının Cinsiyetlerine Göre Dağglımı

\begin{tabular}{lll}
\hline Cinsiyet & Frekans (f) & Yüzde (\%) \\
\hline Kadın & 37 & 88.1 \\
\hline Erkek & 5 & 11.9 \\
\hline Toplam & $\mathbf{4 2}$ & $\mathbf{1 0 0}$ \\
\hline
\end{tabular}

Araştırmaya katılan fen bilgisi öğretmen adaylarının 37'si (\%88.1) kadın ve 5'i (\%11.9) erkek olmak üzere toplam 42'dir.

\section{Veri Toplama Araçları}

$\mathrm{Bu}$ çalışmada fen bilgisi öğretmen adaylarının yoğuşma ve yoğunlaşma kavramlarına yönelik görüşlerinin belirlenmesi için veri toplama metodu olarak açık uçlu anket tercih edilmiştir. $\mathrm{Bu}$ kapsamda araştırmacı tarafından hazırlanan ve uzman görüşü alınan yapılandırılmış anket formu kullanılmıştır. Açık uçlu anket kapsamında cevap aranan sorular aşağıdaki gibidir:

1-) Yoğuşma nedir?

2-) Yoğunlaşma nedir?

3-) Yoğuşma ve yoğunlaşmaya ilişkin hangi örnekleri verebilirsiniz?

4-) Size göre yoğuşma ve yoğunlaşmanın varsa farkları nelerdir?

5-) Size göre yoğuşma ve yoğunlaşmanın varsa benzerlikleri nelerdir?

\section{Verilerin Toplanma Süreci}

Veriler Fizik-III dersleri kapsamında toplamda 42 fen bilgisi öğretmen adayının görüşlerinden elde edilmiştir. Verilerin toplanmasında pandemi sürecinden ötürü e-posta sistemi kullanılmıştır. Açık uçlu anket formu fen bilgisi öğretmen adaylarının e-posta adreslerine gönderilmiş ve doldurup göndermeleri rica edilmiştir. Bu bağlamda veri toplama sürecinde gönüllülük esasının dikkate alındığını söylemek pek de yanlış olmayacaktır.

\section{Verilerin Analizi}

Çalışmadan elde edilen verilerin analizinde betimsel analizden faydalanılmıştır. Betimsel analizde temel amaç, toplanan verileri açıklayabilecek kavramlara ve ilişkilere ulaşmaktır. Daha önceden belirlenen (konuya uygun biçimde) ya da belirlenmiş olan kategori ve temalara uygun olarak verilerin kodlanması, temaların bulunması, kodların ve temaların düzenlenmesi, bulguların tanımlanması ve yorumlanması olarak dört aşamada analiz edilir (Çepni, 2014). Verilerden ortaya çıkan kodlara ve kategorilere göre veriler düzenlenip 
yorumlanmıştır. Araştırmanın amacına uygun olması için gerekli kodlar seçilmiş ve kodları belirli kategoriler altında toplayabilen kategoriler oluşturulmuştur. Fen bilgisi öğretmen adaylarının yoğuşma ve yoğunlaşmaya ve bu iki kavramının farklarına ilişkin görüşleri düzeylerine göre bir arada toplanmıştır. Burada amaç verilen cevapların bilimsel olarak kabul edilip edilemeyeceği ve kısmen kabul edilebileceği şeklinde düzeylerine göre gruplandırılmasıdır (Ayvacı, Alev ve Yıldız, 2015; Güler ve Şahin, 2017). Gruplandırma sürecinde fen bilgisi eğitimi alan uzmanı tarafından kavramsal olarak değerlendirme yapılmıştır. Fen bilgisi öğretmen adaylarının görüşlerinden doğrudan alıntılar yapılarak açıklanmaya çalışılmıştır.

\section{Nitel Veri Toplama Sürecine İlişkin Niteliğin Arttırılmasına Yönelik Alınan Önlemler}

Çalışmada geçerlik ve güvenirlik anlamında gerekli önlemler alınmaya çalışılmıştır. Araştırma niteliğinin artırılmasına yönelik strateji ve işlemler Tablo 2'de verilmiştir (Ayvacı ve diğ., 2015; Y1ldırım ve Şimşek, 2018).

Tablo 2. Araştırma Niteliğinin Artırılmasına Yönelik Stratejiler ve İşlemler

\begin{tabular}{|c|c|c|}
\hline Özellik & Strateji & İșlem \\
\hline \multirow{3}{*}{ 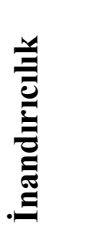 } & Uzman İncelemesi & Veri toplama aracı geliş̧irilirken uzman görüşlerinden yararlanııldı. \\
\hline & Katılımcı Teyidi & Süreç detaylı bir biçimde betimlendi. \\
\hline & & Benzer çalışmaların sonuçları ile desteklenmeye çalışıldı. \\
\hline \multirow{4}{*}{ 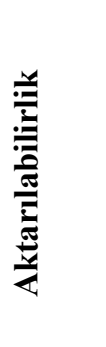 } & & $\begin{array}{l}\text { Calışma grubunun belirlenmesinde amaçlı örnekleme yöntemi } \\
\text { kullanıldı. }\end{array}$ \\
\hline & Amaçlı Örnekleme & Bulgulara araştırmacı yorumları dahil edilmemeye dikkat edildi. \\
\hline & Ayrintil1 & Araştırma süreci detaylı bir biçimde raporlandı. \\
\hline & Betimleme & Doğrudan katılımcı görüşlerine yer verildi. \\
\hline 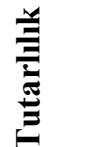 & $\begin{array}{l}\text { Tutarlllik } \\
\text { İncelemesi }\end{array}$ & Veriler, kodlandıktan sonra benzer çalışmalarla karşılaștııııdı. \\
\hline \multirow{3}{*}{ 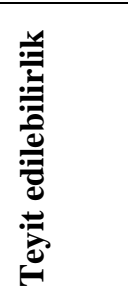 } & & Elde edilen verilere göre süreç detaylı olarak betimlendi. \\
\hline & & Elde edilen veriler muhafaza edildi. \\
\hline & Teyit İncelemesi & $\begin{array}{l}\text { Fen bilgisi öğretmen adaylarının vermiş oldukları cevaplardan } \\
\text { baziları doğrudan alıntı yapılarak ilave edildi. }\end{array}$ \\
\hline
\end{tabular}


Tablo 2'de görüldüğü gibi nitel araştırmalarda inandırıcılık, aktarılabilirlik, tutarlılık ve teyit edilebilirlik kavramları ile geçerlik ve güvenirlik incelenmektedir.

1-) İnandırıcılık: Geçerlik kavramına karşılık gelen bu kavrama yönelik çalışmada uzman incelemesi ve katılımcı teyidi stratejileri doğrultusunda belirli önlemler alınmaya çalışılmıştır. Çalışmanın okuyucu açısından inandırıcılığını artırmak için veri toplama aracı geliştirilirken uzman görüşlerinden yararlanılmıştır. Süreç detaylı bir biçimde betimlenerek, benzer çalışmaların sonuçları ile desteklenmeye çalışılmıştır.

2-) Aktarılabilirlik: Çalışmada aktarılabilirliği artırmak için amaçlı örnekleme ve süreci ayrıntılı betimleme stratejilerine yönelik belirli önlemler alınmaya çalışılmıştır. Bu doğrultuda çalışma grubunun belirlenmesinde amaçlı örnekleme yoluna gidilmiştir. Bulgulara yorum katılmadan okuyucuya aktarılmaya çalışılmıştır. Araştırma süreci detaylı bir biçimde raporlanarak doğrudan katılımcı görüşlerine yer verilmiştir.

3-) Tutarlılık: Araştırmada tutarlılı̆̆ın incelenmesi kapsamında veriler kodlandıktan sonra benzer çalışmalarla karşılaştırılmıştır.

4-) Teyit Edilebilirlik: Araştırmada teyit incelemesi kapsamında elde edilen verilere göre süreç detaylı olarak betimlenmiştir. Elde edilen veriler muhafaza edilmiştir. Ayrıca ham verilerden bazıları doğrudan alıntı yapılarak bulgulara eklenmiştir.

Ayrıca etik çerçeve kapsamında gerekli izinler alınmıştır. Fen bilgisi öğretmen adaylarının katılımlarının gönüllü olmasına dikkat edilmiştir. Araştırma sonuçları raporlaştırılırken öğretmen adaylarının isimleri gizli tutulmuştur.

\section{Bulgular}

Araştırmaya katılan fen bilgisi öğretmen adaylarının yoğuşma ve yoğunlaşma kavramlarına yönelik görüşleri ile ilgili bulgulara yer verilmiştir. Elde edilen veriler içerik analizine göre çözümlenmiştir. Analiz sonuçları tablolar halinde sunularak doğrudan alıntı yapılarak görüşlere yer verilmiştir.

Fen bilgisi öğretmen adaylarının yoğuşmaya ilişkin görüşlerinin belirlenmesi amacıyla veri toplama aracında "Yoğuşma nedir?” sorusuna yer verilmiştir. Öğretmen adaylarının bu soruya ilişkin yanıtlarının tanımlama düzeylerine göre dağılımları örnek cevaplar ile özetlenmeye çalışılmış ve Tablo 3 'te sunulmuştur.

Tablo 3. Fen Bilgisi Öğretmen Adaylarının Yoğuşma Kavramını Tanımlama Düzeyleri 


\begin{tabular}{|c|c|c|}
\hline \multicolumn{3}{|l|}{ Bilimsel Olarak Kabul Edilebilir } \\
\hline Hal değişimi & Ö1, Ö2, Ö4, Ö21, Ö30, Ö35, Ö41 & 7 \\
\hline Maddenin gaz fazı enerji kaybeder & $\begin{array}{l}\text { Ö2, Ö4, Ö7, Ö11, Ö12, Ö19, Ö22, Ö24, } \\
\text { Ö25, Ö28, Ö31, Ö33, Ö36, Ö37, Ö38, Ö39 }\end{array}$ & 16 \\
\hline $\begin{array}{l}\text { Gaz haldeki fazın çevresine isı vererek sıvıya dönüşmesi } \\
\text { (buharlaşmanın tersi) }\end{array}$ & $\begin{array}{l}\text { Ö1, Ö2, Ö3, Ö8, Ö10, Ö11, Ö14, Ö21, } \\
\text { Ö30, Ö32, Ö38, Ö42 }\end{array}$ & 12 \\
\hline \multicolumn{3}{|l|}{ Bilimsel Olarak Kısmen Kabul Edilebilir } \\
\hline Gazdan sıvı hale geçiş & $\begin{array}{l}\text { Ö10, Ö16, Ö18, Ö22, Ö23, Ö24, Ö25, Ö26, } \\
\text { Ö34, Ö35, Ö36, Ö39, Ö41 }\end{array}$ & 13 \\
\hline $\begin{array}{l}\text { Atmosferdeki su buharının gazdan sıvı veya katıya } \\
\text { dönüşmesi }\end{array}$ & $\begin{array}{l}\text { Ö1, Ö2, Ö4, Ö5, Ö6, Ö7, Ö11, Ö14, Ö19, } \\
\text { Ö20, Ö24, Ö25, Ö27, Ö28, Ö29, Ö31, } \\
\text { Ö33, Ö37, Ö39, Ö40 }\end{array}$ & 20 \\
\hline Temel etmen soğumadır & Ö2, Ö4, Ö6, Ö7, Ö14, Ö21, Ö22, Ö41 & 8 \\
\hline \multicolumn{3}{|l|}{ Tablo 3'ün devamı } \\
\hline Cevaplar & Öğretmen Adayları & $\begin{array}{c}\text { Siklık } \\
\text { (f) }\end{array}$ \\
\hline $\begin{array}{l}\text { Sıcaklı̆̆ sabitken basınç artarsa kaynama noktası artar } \\
\text { ve buhar yoğuşur. }\end{array}$ & Ö14 & 1 \\
\hline \multicolumn{3}{|l|}{ Bilimsel Olarak Kabul Edilemez } \\
\hline $\begin{array}{l}\text { Gazın, sıvı veya katıya geçişi kendiliğinden } \\
\text { gerçekleşmez }\end{array}$ & Ö2 & 1 \\
\hline $\begin{array}{l}\text { Yapp elemanlarının iç kısımlarında oluşan ve } \\
\text { başlangıçta gözle fark edilemeyen su birikimi } \\
\text { yoğuşmadır }\end{array}$ & Ö5 & 1 \\
\hline $\begin{array}{l}0 \text { ile } 100 \text { santigrat derece arasındaki tüm sıcaklıklarda } \\
\text { meydana gelirken, bir cisim ve içerisinde bulunduğu } \\
\text { ortam arasındaki sıcaklık farkı arttıkça daha da belirgin } \\
\text { hale gelir }\end{array}$ & Ö9, Ö24, Ö39 & 3 \\
\hline Literatüre yeni eklenmiş bir kelime & Ö1, Ö21 & 2 \\
\hline Yoğunlaşmanın gerçekleşmeden hemen önceki ortam & Ö15 & 1 \\
\hline En sık su döngüsü anlamında kullanılır & Ö26 & 1 \\
\hline
\end{tabular}

Tablo 3 incelendiğinde, fen bilgisi öğretmen adaylarının yoğuşma kavramının ne olduğu konusunda vermiş oldukları cevapların büyük çoğunluğunun "Bilimsel Olarak Kısmen Kabul Edilebilir" nitelikte olduğu görülmektedir. Vermiş oldukları cevaplara göre öğretmen adaylarının bir kısmının "Bilimsel Olarak Kabul Edilebilir" nitelikte cevaplar verdikleri görülmektedir. Daha az bir oranda da "Bilimsel Olarak Kabul Edilemez” nitelikte cevaplar verdikleri görülmektedir. "Bilimsel Olarak Kısmen Kabul Edilebilir" niteliğinde verilen cevapların büyük çoğunluğunun "Atmosferde bulunan su buharının gaz fazından sıvı veya katı fazına dönüşmesi" şeklinde olduğu görülmektedir. "Bilimsel Olarak Kabul Edilebilir" niteliğinde verilen cevapların büyük çoğunluğunun "Bu olay gerçekleşirken maddenin gaz fazı enerji yani ısı kaybeder." şeklinde olduğu görülmektedir. "Bilimsel Olarak Kabul Edilemez" niteliğinde verilen cevapların büyük çoğunluğunun " 0 ile 100 santigrat derece arasındaki tüm sıcaklıklarda meydana gelirken, bir cisim ve içerisinde bulunduğu ortam arasındaki sıcaklık fark1 arttıkça daha da belirgin hale gelir.” şeklinde olduğu görülmektedir. Yoğuşma kavrmına yönelik olarak fen bilgisi öğretmen adaylarının vermiş oldukları cevaplara ilişkin örnekler aşağıdaki gibidir: 
YYÜ Eğitim Fakültesi Dergisi (YYU Journal of Education Faculty), 2021;18(2)56-80,http://efdergi.yyu.edu.tr,

Ö2: Atmosferde bulunan su buharının gaz fazından sıvı veya katı fazına dönüşmesi olarak da tanimlayabiliriz.

Ö4: Gaz ısı kaybeder ve gaz ortama ısı verdiği içinde ortam sıcaklı̆̆ını arttırır.

Ö9: 0 ile 100 santigrat derece arasındaki tüm slcaklıklarda meydana gelirken, bir cisim ve içerisinde bulunduğu ortam arasındaki sıcaklık farkı arttıkça daha da belirgin hale gelir.

Fen bilgisi öğretmen adaylarının yoğunlaşmaya ilişkin görüşlerinin belirlenmesi amacıyla veri toplama aracında ikinci soruya yer verilmiştir. Burada "Yoğunlaşma nedir?" sorusuna yer verilmiştir. Öğretmen adaylarının bu soruya ilişkin yanıtlarının tanımlama düzeylerine göre dağılımları örnek cevaplar ile özetlenmeye çalışılmış ve Tablo 4'te sunulmuştur.

Tablo 4. Fen Bilgisi Öğretmen Adaylarının Yoğunlaşma Kavramını Tanımlama Düzeyleri

\begin{tabular}{|c|c|c|}
\hline Cevaplar & Öğretmen Adayları & $\begin{array}{l}\text { Siklık } \\
\text { (f) }\end{array}$ \\
\hline \multicolumn{3}{|l|}{ Bilimsel Olarak Kabul Edilebilir } \\
\hline $\begin{array}{l}\text { Tanecik sıkılığının veya kıvamının artmasıyla ilgili bir } \\
\text { kavram (hal değişimi değil) }\end{array}$ & Ö1, Ö2, Ö5, Ö10, Ö14, Ö22, Ö30, Ö41 & 8 \\
\hline Doğal bir olay & Ö21, Ö25 & 2 \\
\hline $\begin{array}{l}\text { Yoğunlaşma ve buharlaşma için tek bir sıcaklık söz } \\
\text { konusu değildir. }\end{array}$ & Ö24 & 1 \\
\hline Tanecikler arasında bulunan boşluğun artması & Ö36 & 1 \\
\hline Gözle direk gözlemlenemeyen bir doğal olay & Ö21 & 1 \\
\hline \multicolumn{3}{|l|}{ Bilimsel Olarak Kısmen Kabul Edilebilir } \\
\hline Kendiliğinden gerçekleşir. & Ö3, Ö14, Ö15, Ö23, Ö42 & 5 \\
\hline Yağmurun oluşmasına neden olmas1 & Ö6, Ö21 & 2 \\
\hline $\begin{array}{l}\text { Ortaya çıkan sıvının hacmi gazın hacminden daha } \\
\text { küçüktür }\end{array}$ & Ö11 & 1 \\
\hline $\begin{array}{l}\text { Maddenin fiziksel halindeki bu değişime, basınç veya } \\
\text { sıcaklıktaki bir farklılık neden olabilir (Bu süreç } \\
\text { kendiliğinden gerçekleşmez) }\end{array}$ & $\begin{array}{l}\text { Ö3, Ö12, Ö15, Ö18, Ö23, Ö24, Ö25, Ö27, } \\
\text { Ö34, Ö38, Ö39 }\end{array}$ & 11 \\
\hline Dışarıya 1sı verilir & $\begin{array}{l}\text { Ö1, Ö3, Ö4, Ö5, Ö7, Ö8, Ö9, Ö10, Ö11, } \\
\text { Ö12, Ö13, Ö16, Ö17, Ö19, Ö27, Ö32, Ö37, } \\
\text { Ö40, Ö42 }\end{array}$ & 19 \\
\hline Sıcaklık azaldığında yoğunlaşma hızı artar & Ö16 & 1 \\
\hline $\begin{array}{llll}\begin{array}{l}\text { Su buharının yoğunlaşarak } \\
\text { getirmesidir }\end{array} & \text { bulutları meydana } \\
\end{array}$ & Ö29 & 1 \\
\hline \multicolumn{3}{|l|}{ Bilimsel Olarak Kabul Edilemez } \\
\hline Yoğuşma ve yoğunlaşma aynı olaydır & $\begin{array}{l}\text { Ö3, Ö5, Ö13, Ö17, Ö25, Ö32, Ö33, Ö35, } \\
\text { Ö36, Ö42 }\end{array}$ & 10 \\
\hline $\begin{array}{l}\text { Gaz halindeki bir maddenin sıvı hale dönüşme süreci } \\
\text { (buharlaşmanın tersi, hal değişimi) }\end{array}$ & $\begin{array}{l}\text { Ö3, Ö4, Ö5, Ö7, Ö8, Ö9, Ö10, Ö12, Ö13, } \\
\text { Ö15, Ö16, Ö17, Ö18, Ö19, Ö20, Ö23, Ö24, } \\
\text { Ö25, Ö28, Ö31, Ö32, Ö34, Ö35, Ö37, Ö38, } \\
\text { Ö39, Ö40, Ö42 }\end{array}$ & 28 \\
\hline Su buharının gözle görülür hale gelmesi & Ö1, Ö6, Ö14 & 3 \\
\hline Su döngüsü & Ö25, Ö26 & 2 \\
\hline Bulutlardaki gazın sıvı veya katıya dönüşmesi & Ö11, Ö21, Ö26, Ö28, Ö36, Ö37, Ö38, Ö39 & 8 \\
\hline
\end{tabular}

Tablo 4 incelendiğinde, fen bilgisi öğretmen adaylarının yoğunlaşma kavramının ne olduğu konusunda vermiş oldukları cevapların büyük çoğunluğunun "Bilimsel Olarak Kabul 
Edilemez" nitelikte olduğu görülmektedir. Vermiş oldukları cevaplara göre öğretmen adaylarının bir kısmının "Bilimsel Olarak Kısmen Kabul Edilebilir” nitelikte görüşlere sahip oldukları görülmektedir. Daha az bir oranda da "Bilimsel Olarak Kabul Edilebilir” nitelikte cevaplar verdikleri görülmektedir. "Bilimsel Olarak Kabul Edilemez" niteliğinde verilen cevapların büyük çoğunluğunun "Gaz halindeki bir maddenin sıvı hale dönüşme sürecidir, buharlaşmanın tersidir yani hal değişimi” şeklinde olduğu görülmektedir. "Bilimsel Olarak Kısmen Kabul Edilebilir" niteliğinde verilen cevapların büyük çoğunluğunun "Yoğunlaşma olayı gerçekleşirken dışarıya 1sı verilir." şeklinde olduğu görülmektedir. "Bilimsel Olarak Kabul Edilebilir” niteliğinde verilen cevapların büyük çoğunluğunun “Tanecik sıkılığının veya kıvamının artmasıyla ilgili bir kavramdır, sadece hal değişimi değildir." şeklinde olduğu görülmektedir. Yoğunlaşma kavramına ilişkin fen bilgisi öğretmen adaylarının vermiş oldukları cevaplara ilişkin örnekler aşağıdaki gibidir:

Ö4: Buharlaşma olayının tersi olarak da biliyoruz. Maddenin fiziksel halinin isı vererek gaz halinden sıvı haline geçmesidir.

Ö2: Bu olay gerçekleşirken maddenin gaz fazı enerji yani ısı kaybeder ve kaybettiği ısıyı çevresine verir yani ekzotermik bir olaydır diyebiliriz.

Ö10: Bir maddenin taneciklerinin birbirine yaklaşarak kıvamının artması olarak tanımlanabilir. Hal değişimi olan yoğuşma ile karıştırılsa da yoğunlaşma tam anlamıyla bir hal değişimi değildir.

Fen bilgisi öğretmen adaylarının yoğuşma ve yoğunlaşmanın örneklerine yönelik “Yoğuşma ve yoğunlaşmaya ilişkin hangi örnekleri verebilirsiniz?” sorusuna ilişkin yanıtları örnek cevaplar ile özetlenmeye çalışılmış ve Tablo 5'te sunulmuştur.

Tablo 5. Fen Bilgisi Öğretmen Adaylarının Yoğuşma ve Yoğunlaşma Örneklerine İlişkin Görüşleri

\begin{tabular}{|c|c|c|}
\hline Cevaplar & Öğretmen Adayları & $\begin{array}{c}\text { Siklık } \\
\text { (f) }\end{array}$ \\
\hline Yoğuşmalı kombiler & $\begin{array}{l}\text { Ö1, Ö4, Ö5, Ö7, Ö8, Ö14, Ö15, Ö16, Ö21, } \\
\text { Ö22, Ö25, Ö29, Ö31, Ö39 }\end{array}$ & 14 \\
\hline Dolaptan çıkan şişenin etrafinda damlacıklar oluşması & $\begin{array}{l}\text { Ö2, Ö6, Ö7, Ö10, Ö11, Ö14, Ö15, Ö16, } \\
\text { Ö17, Ö18, Ö20, Ö22, Ö23, Ö24, Ö27, Ö30, } \\
\text { Ö32, Ö34, Ö35, Ö36, Ö39, Ö40, Ö41, Ö42 }\end{array}$ & 24 \\
\hline Jet uçaklarının bıraktığı iz & Ö3 & 1 \\
\hline $\begin{array}{l}\text { Camda veya aynada oluşan buhar (araba camı veya } \\
\text { tencere kapağı) }\end{array}$ & $\begin{array}{l}\text { Ö1, Ö2, Ö4, Ö5, Ö6, Ö7, Ö8, Ö9, Ö10, } \\
\text { Ö11, Ö12, Ö13, Ö14, Ö16, Ö17, Ö18, Ö19, } \\
\text { Ö20, Ö21, Ö22, Ö23, Ö24, Ö25, Ö26, Ö27, } \\
\text { Ö28, Ö29, Ö30, Ö32, Ö33, Ö34, Ö35, Ö36, } \\
\text { Ö37, Ö38, Ö39, Ö40, Ö41, Ö42 }\end{array}$ & 39 \\
\hline $\begin{array}{l}\text { Hava olayları (kırağı, dolu, yağmur, kar, bulut, sis, çiy } \\
\text { gibi). }\end{array}$ & $\begin{array}{l}\text { Ö1, Ö2, Ö3, Ö4, Ö5, Ö6, Ö7, Ö8, Ö9, Ö10, } \\
\text { Ö11, Ö12, Ö14, Ö16, Ö18, Ö19, Ö20, Ö21, } \\
\text { Ö22, Ö24, Ö26, Ö27, Ö28, Ö29, Ö30, Ö31, }\end{array}$ & 35 \\
\hline
\end{tabular}




\begin{tabular}{lll}
\hline & $\begin{array}{l}\text { Ö32, Ö33, Ö35, Ö36, Ö37, Ö38, Ö39, Ö40, } \\
\text { Ö41 }\end{array}$ & 1 \\
\hline Sütü kaynattıkça kaymak elde etmek & Ö10 & 2 \\
\hline $\begin{array}{l}\text { Çimentonun havayla temas ettikçe kuruyup katılaşmas1 } \\
\text { Tinerli bir boya içindeki tiner uçtukça boyanın } \\
\text { koyulaşması }\end{array}$ & Ö10 & 1 \\
\hline Damıtma yoluyla arıtılmış bazı sıvlların üretimi & Ö11, Ö20, Ö21 & 3 \\
\hline $\begin{array}{l}\text { Elektrik enerjisinin önemli bölümünün buhar } \\
\text { türbinleriyle üretilmesi }\end{array}$ & Ö11 & 1 \\
\hline Nemin duvarlara yerleşmesi & Ö14 & 1 \\
\hline Parfümler & Ö15, Ö30 & 2 \\
\hline Piknik tüpleri, sanayi tüpü, doğal gaz & Ö15 & 1 \\
\hline
\end{tabular}

Tablo 5 incelendiğinde, fen bilgisi öğretmen adaylarının yoğuşma ve yoğunlaşma kavramlarına ilişkin vermiş oldukları örneklerin büyük çoğunluğunun "Camda veya aynada buhar oluşumu" şeklinde olduğu görülmektedir. Fen bilgisi öğretmen adayları yakın bir oranda da "Hava olayları yoğunlaşmaya örnektir (kırağı, dolu, yağmur, kar, bulut, sis,çiy gibi)." cevabını vermişlerdir. Yoğuşma ve yoğunlaşma örneklerine ilişkin fen bilgisi öğretmen adaylarının vermiş oldukları cevaplara ilişkin örnek görüşler aşağıdaki gibidir:

Ö20: Kaynayan tencerenin kapağında oluşan su damlacıkları, havanın sisli olma durumu, sabah saatlerinde oluşan çiy olayı ve bulutların oluşumu örnek verilebilir.

Ö26: Genellikle klş aylarında camlarda buğu oluştuğunu görürüz. Yağmur, kıră̆ı, dolu, bulut, kar gibi doğa olayları örnektir. Sis örnektir. Banyo yaptıktan sonra banyonun aynasında oluşan buhar örnektir.

Fen bilgisi öğretmen adaylarının yoğuşma ve yoğunlaşmanın farklarına yönelik "Size göre yoğuşma ve yoğunlaşmanın varsa farkları nelerdir?” sorusuna yanıtları örnek cevaplar ile özetlenmeye çalışılmış ve Tablo 6'da sunulmuştur.

Tablo 6. Fen Bilgisi Öğretmen Adaylarının Yoğuşma ve Yoğunlaşmanın Farklarına İlişkin Görüşleri

\begin{tabular}{|c|c|c|}
\hline Cevaplar & Öğretmen Adayları & $\begin{array}{c}\text { Siklık } \\
\text { (f) }\end{array}$ \\
\hline \multicolumn{3}{|l|}{ Bilimsel Olarak Kabul Edilebilir } \\
\hline $\begin{array}{l}\text { Yoğuşma gazın sıvı hale geçmesiyken, yoğunlaşma ise } \\
\text { tanecik sıkıllğının artmasıyla ilgili bir kavramdır }\end{array}$ & $\begin{array}{l}\text { Ö2, Ö4, Ö10, Ö12, Ö27, Ö36, Ö37, Ö38, } \\
\text { Ö39, Ö40, Ö41 }\end{array}$ & 11 \\
\hline $\begin{array}{l}\text { Yoğuşmanın olduğu her yerde yoğunlaşma vardır ancak } \\
\text { yoğunlaşma olan her yerde yoğuşma yoktur. } \\
\text { (Yoğuşma bir hal değişimidir ve uygun şartlar } \\
\text { oluştuğunda gerçekleşir. Yoğunlaşma ise sadece hal } \\
\text { değişimlerinde gözlenmez bir gazı alıp uygun bir } \\
\text { düzenek ile skisıţıırısak gaz yine yoğunlaşır ancak } \\
\text { yoğuşma gözlenmez. ) }\end{array}$ & Ö30 & 1 \\
\hline \multicolumn{3}{|l|}{ Bilimsel Olarak Kısmen Kabul Edilebilir } \\
\hline $\begin{array}{l}\text { Yoğuşma atmosferdeki nemin gaz halinden sıvı hale } \\
\text { geçmesidir, bir hal değişimidir. Yoğunlaşma ise } \\
\text { havadaki gözle göremediğimiz su buharının gözümüzle } \\
\text { görülecek hale gelme durumu, yağış }\end{array}$ & Ö1, Ö20, Ö29 & 3 \\
\hline
\end{tabular}


Yoğuşma kendiliğinden gerçekleşmezken (dışarıdan bir Ö3, Ö14, Ö28, Ö31, Ö42, Ö22, Ö41 basınç vb. lazım.) yoğunlaşma kendiliğinden gerçekleşir

Yoğunlaşma hal değişimi, yoğuşma yoğunlaşmanın gerçekleştiği ortam

Yoğunlaşma esnasında tanecik sıklığ1, yoğunluğu Ö22 artarken, yoğuşma esnasında sabittir

\begin{tabular}{lll}
\hline Bilimsel Olarak Kabul Edilemez & & \\
\hline Yoğuşma yoğunlaşmadan sonra gerçekleşir & Ö11 & 1 \\
\hline Yoğunlaşma olay, yoğuşma sonuçtur & Ö31 & 1 \\
\hline $\begin{array}{l}\text { Yoğunlaşmanın gerçekleşmesi için doyma noktasına } \\
\text { ulaşması gerek, yoğuşmada böyle bir gerekçe yoktur }\end{array}$ & Ö11 & \\
\hline Boş & & \\
\hline
\end{tabular}

Tablo 6 incelendiğinde, Fen bilgisi öğretmen adaylarının yoğuşma ve yoğunlaşmanın farklarına ilişkin vermiş oldukları cevapların büyük çoğunluğunun "Bilimsel Olarak Kısmen Kabul Edilebilir” nitelikte olduğu görülmektedir. Vermiş oldukları cevaplara göre öğretmen adaylarının bir kısmının "Bilimsel Olarak Kabul Edilebilir" nitelikte görüşlere sahip oldukları görülmektedir. Daha az bir oranda da "Bilimsel Olarak Kabul Edilemez” nitelikte cevaplar verdikleri ve boş bıraktıkları görülmektedir. "Bilimsel Olarak Kabul Kısmen Edilebilir" niteliğinde verilen cevapların büyük çoğunluğunun "Yoğuşma kendiliğinden gerçekleşmezken (dışarıdan bir basınç vb. lazım.) yoğunlaşma kendiliğinden gerçekleşir." ş̧eklinde olduğu görülmektedir. "Bilimsel Olarak Kabul Edilebilir" niteliğinde verilen cevapların büyük çoğunluğunun "Yoğuşma gazın sıvı hale geçmesiyken, yoğunlaşma ise tanecik sıkılığının artmasıyla ilgili bir kavramdır.” ş̧eklinde olduğu görülmektedir. Yoğuşma ve yoğunlaşmanın farklarına ilişkin fen bilgisi öğretmen adaylarının vermiş oldukları cevaplara ilişkin örnekler aşağıdaki gibidir:

Ö3: Yoğuşma kendiliğinden gerçekleşmezken yoğunlaşma kendiliğinden gerçekleşir. Kendinden gerçekleşmez derken dışarıdan bir basınç vb. lazım.

Ö39: Yoğuşma gazın sıvı hale geçmesi yoğunlaşma tanecik sıklı̆̆ının artmasıdır yoğuşan madde daha da yoğunlaşır yoğuşma bir haldir.

Ö11: Yoğunlaşma olayının gerçekleşmesi için doyma noktasına ulaşması gerek yoğuşmada böyle bir gerekçe yoktur.

Fen bilgisi öğretmen adaylarının yoğuşma ve yoğunlaşmanın benzerliklerine yönelik “Size göre yoğuşma ve yoğunlaşmanın varsa benzerlikleri nelerdir?” sorusuna ilişkin yanıtları örnek cevaplar ile özetlenmeye çalışılmış ve Tablo 7'de sunulmuştur.

Tablo 7. Fen Bilgisi Öğretmen Adaylarının Yoğuşma ve Yoğunlaşmanın Benzerliklerine İlişkin Görüşleri

\begin{tabular}{lcc}
\hline Cevaplar & Öğretmen Adayları & $\begin{array}{c}\text { Sıklık } \\
\text { (f) }\end{array}$ \\
\hline Boș & & \\
\hline
\end{tabular}




\begin{tabular}{llc}
\hline Cevap yok & $\begin{array}{l}\text { Ö2, Ö7, Ö12, Ö13, Ö22, Ö23, Ö26, Ö30, Ö34, Ö39, } \\
\text { Ö41 }\end{array}$ & 11 \\
\hline Hal Değişimi & & 20 \\
\hline Aynı olay & $\begin{array}{l}\text { Ö1, Ö3, Ö5, Ö9, Ö11, Ö16, Ö17, Ö18, Ö19, Ö20, } \\
\text { Ö24, Ö25, Ö27, Ö28, Ö32, Ö33, Ö35, Ö36, Ö40, } \\
\text { Ö42 }\end{array}$ & 2 \\
\hline $\begin{array}{l}\text { Her ikisinde de su buharı gazdan sıvıya ya da } \\
\text { katıya dönüşür }\end{array}$ & Ö6, Ö14 & 1 \\
\hline İkisinde de nemin artması olay1 vardır & Ö14 & 8 \\
\hline İki olay da gazdan siviya geçerken gerçekleşir & Ö1, Ö10, Ö11, Ö15, Ö17, Ö28, Ö31, Ö38 & 1 \\
\hline Yoğunluk & & 1 \\
\hline İkisinde de tanecikler arası mesafe azalır & Ö10 & \\
\hline İkisinde de yoğunluk artar & Ö10 & \\
\hline
\end{tabular}

\section{Tablo 7'nin devamı}

\begin{tabular}{llc}
\hline Cevaplar & Öğretmen Adayları & $\begin{array}{c}\text { Sıklık } \\
\text { (f) }\end{array}$ \\
\hline Isı-Sıcaklık & & \\
\hline Her iki olayda dışarıya 1Sı verilir ve sıcaklık değişmez. & $\begin{array}{l}\text { Ö1, Ö4, Ö8, Ö10, Ö11, Ö14, Ö15, Ö21, } \\
\text { Ö29, Ö37, Ö38 }\end{array}$ & 11 \\
\hline
\end{tabular}

Tablo 7 incelendiğinde, Fen bilgisi öğretmen adaylarının yoğuşma ve yoğunlaşmanın benzerliklerine ilişkin vermiş oldukları cevapların büyük çoğunluğunun "Hal Değişimi" kategorisi altında toplanarak, hal değişimine ilişkin açıklamalar yapıldığı görülmektedir. "Hal Değişimi”" kategorisi altında verilen cevapların en çok "Yoğuşma ve yoğunlaşma aslında aynı olaydır." şeklinde olduğu görülmektedir. Vermiş oldukları cevaplara göre öğretmen adaylarının bir kısmının yoğuşma ve yoğunlaşmanın benzerliklerini 1sı ve sıcaklık ilişkisine dayalı olarak açıklamaya çalıştıkları görülmüştür. $\mathrm{Bu}$ görüşleri de "Isı-Sıcaklık" kategorisi altında toplanmıştır. Sadece bir öğretmen adayının da yoğunluk kavramı ile ilişki kurarak açıklama yapmaya çalıştığı görülmüştür. Öğretmen adayının buna ilişkin görüşleri de "Yoğunluk" kategorisi altında toplanmıştır. Yoğuşma ve yoğunlaşmanın benzerliklerine ilişkin fen bilgisi öğretmen adaylarının vermiş oldukları cevaplara ilişkin örnekler aşağıdaki gibidir:

Ö32: Yoğuşma ve yoğunlaşma aynı şey.

Ö29: Her iki olayda dışarıya ısı verilir bu durumda dış ortamı ısıtır. İki olayda sıcaklık değişmez.

Ö10: İkisinde de tanecikler arası mesafe azalır. İkisinde de yoğunluk artar.

\section{Tartışma ve Sonuç}

Fen bilgisi öğretmen adaylarının yoğuşma kavramına ilişkin verdikleri cevaplara bakıldığında genel olarak "Bilimsel Olarak Kısmen Kabul Edilebilir” nitelikte cevaplar verdikleri görülmektedir. Çoğunlukla "Atmosferde bulunan su buharının gaz fazından sıvı fazına dönüşmesi” şeklinde oldukları görülmektedir. Büyük çoğunluğunun ise "Bu olay 
gerçekleşirken maddenin gaz fazı enerji yani 1sı kaybeder.” şeklinde cevaplar vererek olayın fiziksel olarak açıklamasını da yapmaya çalıştıları belirlenmiştir. Daha az bir oranda da "Bilimsel Olarak Kabul Edilemez" nitelikte "0 ile 100 santigrat derece arasındaki tüm sıcaklıklarda meydana gelirken, bir cisim ve içerisinde bulunduğu ortam arasındaki sıcaklık farkı arttıkça daha da belirgin hale gelir." şeklinde cevaplar verdikleri görülmektedir (Tablo 3). Fen bilgisi öğretmen adayları yoğuşma kavramına ilişkin kısmen bilimsel kabul edilebilecek düzeyde görüşlere sahiptirler. Yoğuşma, buharlaşma, erime, donma ve süblimleşme maddelerin hal değiştirmelerine verilen kavramsal ifadelerdir. Her biri hal değiş̧irmenin özel bir durumunu ifade eder. Aslında bu kavramlar hal değiştirme sürecinde gerçekleşen olaya verilen adlardır. Buna rağmen örneklemdeki öğrencilerden bir kısmının da kavram yanılgılarına sahip oldukları görülmektedir ve yoğuşma ve yoğunlaşma kavramını birbiri yerine kullanmaktadırlar. Aslında yoğuşan gazlar sıvı forma geçtiklerinde yoğunlaşırlar yani yoğunlukları artar. Birim hacimdeki madde miktarı çoğalır. Bu açıdan bakıldığında doğru gibi görülebilir. Fakat sadece hal değiştirme sürecinde yoğunlaşma gerçekleşmez, örneğin cismin sıcaklığı azaldığında da (özel durumlar hariç "suyun $+4{ }^{0} \mathrm{C}$ nin her iki yanındaki durumu") cisim yoğunlaşır. Bu noktadan değerlendirildiğinde öğretmen adayları bu duruma neredeyse hiç değinmemişlerdir. Öğretmen adaylarının bu duruma değinmemiş olmalarında anlamsal ve kavramsal boyutta eksiklere sahipi olduğunun bir göstergesi olarak kabul edilir. Bu duruma benzer biçimde Osborne \& Cosgrove (1983) çalışmalarının sonucunda öğrencilerin buharlaşma, yoğunlaşma ve kaynama gibi kavramlara ilişkin yüzeysel bilgilere sahip olduklarını ve bazı bilimsel olmayan görüşlere de sahip olduklarını belirlemişlerdir.

Fen bilgisi öğretmen adaylarının yoğunlaşma kavramının ne olduğu konusunda vermiş oldukları cevapların büyük çoğunluğunun "Bilimsel Olarak Kabul Edilemez" nitelikte "Gaz halindeki bir maddenin sıvı hale dönüşme sürecidir, buharlaşmanın tersidir yani hal değişimi”” şeklinde olduğu görülmektedir. Az sayıda öğretmen adayın yoğunlaşma kavramı ilgili vermiş oldukları cevaplar kısmen bilimsel olarak kabul edilebilir. Bu durumu öğretmen adayları, "Yoğunlaşma olayı gerçekleşirken dışarıya 1Sı verilir." şeklinde cevaplar verdikleri görülmektedir. Daha az bir oranda da "Bilimsel Olarak Kabul Edilebilir” nitelikte “Tanecik sıkılığının veya kıvamının artmasıyla ilgili bir kavramdır, sadece hal değişimi değildir." şeklinde cevaplar verdikleri görülmektedir (Tablo 4). Öğretmen adayları kısmen kabul edilebilir cevapları verirken bir maddenin birim hacimdeki madde miktarın artırmada sadece sıcaklığın azalmasını dikkate almışlardır. Oysaki sıkıştırma veya saflığını artırmada birim hacimdeki madde miktarını artırabilir. Bu durumlarda madde yoğunlaşır konsantresi artar. Fen 
bilgisi öğretmen adaylarının büyük çoğunluğu yoğunlaşma kavramına ilişkin "bilimsel olarak kabul edilemeyecek” düzeyde görüşlere sahiptirler. Yoğunlaşma kavramını daha çok hal değişimi olarak açıklamanın yanında yoğuşma ve yoğunlaşma kavramlarının aynı olayı açıkladığını düşünmektedirler. Yoğunlaşma kavramına yönelik çok az öğretmen adayının bilimsel olarak kabul edebilecek düzeyde tanecikler arası boşlukla, tanecik sıklığının artması veya yoğunlukla alakalı olduğunu düşündükleri belirlenmiştir. Fen bilgisi öğretmen adayları özellikle yoğunlaşma kavramına ilişkin yanılgılara sahiptirler ve yoğunlaşma kavramını yoğuşma kavramının yerine kullanmaktadırlar. Buradaki var olan problem yoğuşma eylemi içerisinde bir yoğunlaşma süreci yaşanmasından kaynaklanmamaktadır. Öğretmen adayları yoğunlaşmanın bu süreçle tamamlanıp bittiğini düşünmelerinden kaynaklanmaktadır. Oysaki yoğuşan madde sıcaklığı azaldıkça yoğunlaşmaya devam etmektedir. Bu nedenle bu geçiş süreci yeni bir kavramla adlandırılmıştır. Bu kavramsal derinliği algılayamayan bir öğretmen adayı bu fiziksel olayı kendi zihninde tam olarak çözemez ve öğrencilerine de yaşadığı bu yanılgıyı taşıyabilir. Benzer şekilde Coştu (2002) çalışmasının sonucunda ortaöğretim öğrencilerinin yoğunlaşma, buharlaşma ve kaynama kavramlarını anlamada sıkıntı yaşadıklarını tespit etmişstir.

Fen bilgisi öğretmen adaylarının yoğuşma ve yoğunlaşma kavramlarına ilişkin vermiş oldukları örneklerin büyük çoğunluğunun "Camda veya aynada buhar oluşumu” şeklinde somut örneklerden olduğu görülmektedir. Fen bilgisi öğretmen adayları küçük bir oranda da "Hava olayları yoğunlaşmaya örnektir (kırağı, dolu, yağmur, kar, bulut, sis ve çiy gibi)” cevaplar vermişlerdir (Tablo 5). Fen bilgisi öğretmen adayları genel olarak yoğuşmaya ait günlük hayattan hava olaylarına dayalı ve buhar oluşumuna ilişkin örnekler vermişlerdir. Bunun nedeni yoğunlaşmanın yoğuşma dışındaki etkilerinin kolayca ve gözle direk gözlenemeyeceğinden kaynaklanmış olabilir. Fen bilgisi öğretmen adaylarının yoğuşma ve yoğunlaşma kavramının net bir ayırımını yapamıyor olmalarının kanıtı niteliğindedir. Ayrıca ders kitaplarında da yoğuşmaya ilişkin örneklere çok fazla yer verilmesi bunların yoğunlaşma örnekleri olarak sunulması da neden olmuş olabilir. Benzer şekilde Canpolat, Ateş ve Ayyıldız (2019) fen bilgisi öğretmen adaylarının hal değiştirme gibi kimya konularını günlük yaşama transfer etmede yetersiz kaldıklarını ve kavram yanılgılarına sahip olduklarını tespit etmişlerdir.

Fen bilgisi öğretmen adaylarının yoğuşma ve yoğunlaşmanın farklarına ilişkin vermiş oldukları cevapların büyük çoğunluğunun "Bilimsel Olarak Kabul Edilemez” veya "Bilimsel Olarak Kısmen Kabul Edilebilir” nitelikte cevaplar oldukları görülmektedir. Ayrıca öğretmen adaylarının çok az bir kısmı ise "Bilimsel Olarak Kabul Edilebilir” nitelikte cevaplar verdikleri 
görülmektedir. "Yoğuşma gazın sıvı hale geçmesiyken, yoğunlaşma ise tanecik sıkılığının artmasıyla ilgili bir kavramdır” şeklindeki cevap bu duruma bir örnek olarak sunulabilir (Tablo 6). Fen bilgisi öğretmen adayları yoğuşma ve yoğunlaşmanın ayırımını yapamamakta ve kavramları birbiri yerine kullanmaktadırlar. Benzer şekilde Bar \& Travis (1991) öğrencilerin buharlaşma kavramını anlamakta zorluk çektiklerini kaynama kavramı ile karıştırdıklarını belirtmiştir.

Fen bilgisi öğretmen adaylarının yoğuşma ve yoğunlaşmanın benzerliklerine ilişkin vermiş oldukları cevapların büyük çoğunluğunun "Hal Değişimi” kategorisi altında toplanarak, hal değişimine ilişkin açıklamalar yapıldığı görülmektedir. "Hal Değişimi”" kategorisi altında verilen cevapların en çok "Yoğuşma ve yoğunlaşma aslında aynı olaydır." şeklinde olduğu görülmektedir. Vermiş oldukları cevaplara göre öğretmen adaylarının bir kısmının yoğuşma ve yoğunlaşmanın benzerliklerini 1sı ve sıcaklık ilişkisine dayalı olarak açıklamaya çalıştıkları görülmüştür. Bu görüşleri de "Isı-Sıcaklık” kategorisi altında toplanmıştır. Sadece bir öğretmen adayının yoğunluk kavramı ile ilişki kurarak açıklama yapmaya çalıştığı görülmüştür. Öğretmen adayının buna ilişkin görüşleri de "Yoğunluk" kategorisi altında toplanmıştır (Tablo 7). Fen bilgisi öğretmen adayları yoğuşma ve yoğunlaşmanın benzerliklerini hal değişimine yönelik ifadelerle açıklamaktadırlar. Öğretmen adayları yoğuşma ve yoğunlaşmanın aynı olaylar olduğunu düşünmektedirler. Sadece bir öğretmen yoğunlaşma kavramının taneciklerin sıklığı ile alakalı olduğunu, sadece hal değişimi olmadığını düşünmektedir. Benzer şekilde Gökulu (2015) çalışmasının sonucunda sınıf öğretmen adaylarının 1Sı-sıcaklık ve hal değişimi kavramlarına ilişkin kavram yanılgılarına sahip olduklarını tespit etmiştir.

Fen bilgisi öğretmen adaylarının vermiş oldukları cevapların analizleri sonucunda kavram yanılgılarına sahip oldukları belirlenmiştir. Çok az sayıda fen bilgisi öğretmen adayı yoğuşma ve yoğunlaşma kavramının ayrımını kısmen de olsa yapabilmektedir. Fakat öğretmen adaylarının büyük çoğunluğu yoğuşma ve yoğunlaşma kavramını aynı olaylar olarak görmekte ve kavramları birbiri yerine koymaktadırlar. Bunun nedeni ortaokul fen bilgisi ders kitabında ve “Fen Bilimleri Dersi Öğretim Programı”nda yoğuşma ve yoğunlaşma kavramının aynı anlamda kullanılmasından kaynaklanıyor olabilir (MEB, 2018). Bu duruma yönelik olarak Chinn (1995), insanların kavramları anlamlandırması sürecinde bilimsel bilginin zihinde temsil edilmesi, temsil sürecinde çeşitli teorilerin değerlendirilmesi ve uygun teorinin seçilmesi şeklinde üç basamaktan meydana gelen bir sürecin olduğunu vurgulayarak bu süreç içerisinde bireylerin inançlarından, öğrenme alışkanlıklarından ve özellikle de metinlerde dile getirilen durumlar ile zihinlerindeki örüntüler arasındaki ilişkiden kaynaklı olabileceği ifade edilmiştir. 
Dolayısıyla da kitaplarda, belgelerde ya da metinlerde dile getirilen kavramsal hataların ya da kavramsal karmaşanın bireylerde kavram yanılgılarına sebebiyet verdiğini söylemek pek de yanlış olmayacaktır. Öte yandan hızlı gelişimiyle hayatın en önemli parçalarından olan teknolojinin her an bilgi edinmek amacıyla başvurulan kaynakların başında gelmesi ve internet üzerindeki birçok kaynakta da yoğuşma ve yoğunlaşma kavramı birbiri yerine kullanılması da ilgili süreçte etkili olabilecek bir faktördür. Öğretmen adaylarının fen okuryazarı birey olmaktan uzak kalarak doğru bilgiye nasıl ulaşacağını bilmeyerek herhangi bir internet sitesi üzerinden bu tarz yanlış bilgilere ulaşabilirler. Chinn (1995) tarafından da dile getirildiği üzere uygun teorilerin seçilerek tanımlama yapılma sürecinde öğretmen adaylarının yanlış bilgi bütünlüğü ile karşılaşmış olması kavram yanılgısının oluşmasına zemin hazırlamaktadır. Ayrıca gerek bilimsel kitaplarda gerekse de internet ortamı üzerindeki metinlerde yabancı kaynaklardan çeviri yapılarak yoğuşma ve yoğunlaşma kavramlarının tanımlanıyor olması ve yabancı kaynaklarındaki filolojik donanıma sahip olunmaması durumu da öğretmen adaylarının kavramları yanlış teoriler üzerine kurgulamasına sebebiyet verilebilmektedir.

\section{Öneriler}

Yoğuşma ve yoğunlaşma kavramına ilişkin doğru öğrenmelerin gerçekleşmesi için ders kitaplarında ve öğretim programında bu kavramların ayrımına yer verilmelidir. Birbiri yerine kullanılmamasına dikkat edilmelidir. Fen bilgisi öğretmen adaylarının da bu kavramların ayrımını yapabilmesi gereklidir.

Hizmet içi eğitim kapsamında fen bilgisi öğretmenlerinin ve ortaokul öğrencilerinin de bu kavramlara ilişkin yanılgılarının varlığının tespitine ilişskin çalışmalar yapılabilir.

Fen bilgisi öğretmen adaylarının kavram yanılgılarının düzeltilmesine yardımcı olabilmek adına farklı ögretim yöntem ve teknikleri kullanılabilir.

\section{Makalenin Bilimdeki Konumu}

Matematik ve Fen Bilimleri Eğitimi Bölümü/Fen Bilgisi Eğitimi

\section{Makalenin Bilimdeki Özgünlüğü}

Literatürde hal değişimlerine yönelik çalışmalara rastlanmaktadır. Bu çalışmada fen bilgisi öğretmenlerinin yoğuşma ve yoğunlaşmaya, yoğuşma ve yoğunlaşmanın farkları ve benzerliklerine ve örneklerine ilişkin görüşleri detaylıca araştırılmaya çalışılmıştır. 


\section{Etik Kurul Kararı}

Trabzon Üniversitesi Sosyal ve Beşeri Bilimleri Yayın Etik Kurulu'nun, 30/11/2020 tarih ve 81614018-000-E.518 sayılı kararı gereği çalışma açısından Sosyal ve Beşeri Etik Kuralları ve İlkeleri çerçevesinde herhangi bir sakınca olmadığına karar verilmiştir.

\section{Kaynaklar}

American Association for The Advancement of Science [AAAS] (2015). Project 2061 Report. Aydoğan, S., Güneş, B. ve Gülçiçek, Ç. (2003). Isı ve sıcaklık konusunda kavram yanılgıları. Gazi Üniversitesi Gazi Ĕ̆itim Fakültesi Dergisi, 23(2), 111-124.

Ayvacı, H. Ş., Alev, N. ve Yıldız, M. (2014). Öğrenme kazanımlarının tasarlanma sürecine ilişkin lisansüstü öğrencilerinin zihinsel modellerini belirlemeye yönelik bir çalışma. Kastamonu Ĕ̈itim Dergisi, 23(3), 1013-1030.

Bakırcı, H., Subay, S., Midyatlı, F. ve Ünsal, N. (2010). İlköğretim ikinci kademe öğrencilerinin bazı fen kavramlarıyla ilgili düşüncelerinin sınıf seviyesine göre incelenmesi. Abant İzzet Baysal Üniversitesi Ĕ̌itim Dergisi, 10(1), 31-48.

Bar, V. \& Travis, A. S. (1991). Children's views concerning phase changes. Journal of research in science teaching, 28(4), 363-382.

Bozkurt, Ş. B. ve Çakır, H. (2016). Ortaokul öğrencilerinin 21. yüzyıl öğrenme beceri düzeylerinin cinsiyet ve sinıf seviyesine göre incelenmesi. Pamukkale Üniversitesi Ĕ̌itim Fakültesi Dergisi, (39), 69-82.

Buluş-Kırıkkaya, E. ve Güllü, D. (2008). İlköğretim beşinci sınıf öğrencilerinin 1sı-sıcaklık ve buharlaşma-kaynama konularındaki kavram yanılgıları. İlköğretim Online, 7(1), 15-27.

Canpolat, E., Ateş, H. ve Ayyıldız, K. (2019). Fen bilimleri öğretmen adayları kimya bilgilerini günlük yaşamlarıyla ne kadar ilişkilendirebiliyor?. Atatürk Üniversitesi Kazım Karabekir Ĕ̌itim Fakültesi Dergisi, (38), 66-84.

Coştu, B. (2002). Ortaöğretimin farklı seviyelerindeki öğrencilerin buharlaşma, yoğunlaşma ve kaynama kavramlarını anlama düzeylerine ilişkin bir çalışma (Yayınlanmamış yüksek lisans tezi). Karadeniz Teknik Üniversitesi, Fen Bilimleri Enstitüsü, Trabzon.

Coştu, B., Ayas, A., Açıkkar, E. ve Çalık, M. (2007). Çözünürlük konusu ile ilgili kavramlar ne düzeyde anlaş1lıyor?. Boğaziçi Üniversitesi Eğitim Dergisi, 24(2), 13-28.

Collier, J. G. \& Thome, J. R. (1994). Convective boiling and condensation. Oxford: Clarendon Press.

Çepni, S. (2014). Araştırma ve proje çalışmalarına giriş. Trabzon: Celepler Matbaacılık. 
Çepni, S. (2015). Kuramdan uygulamaya fen ve teknoloji öğretimi. Ankara: Pegem Akademi. Gardner, G. C. (1963). Events leading to erosion in the steam turbine. Proceedings of the Institution of Mechanical Engineers, 178(1/23), 593-623.

Gökulu, A. (2015). Sınıf öğretmeni adaylarının “1sı, sıcaklık, hal değişimi” kavramlarını anlama seviyelerine ilişkin bir çalışma.Mersin Üniversitesi Eğitim Fakültesi Dergisi, 11(2), 300-314.

Güler, B. ve Şahin, M. (2017). Fen bilgisi öğretmen adaylarının "elektrik ve manyetizma" konusundaki kavramsal anlamalarının incelenmesi. Dokuz Eylül Üniversitesi Buca Ĕ̈itim Fakültesi Dergisi, (44), 179-193.

Janiuk, R. M. (1993). Theprocess of learningchemistry: A review of thestudies. Journal Chemical Education, 70(10), 828-829.

Karaer, H. (2007). Sınıf öğretmeni adaylarının madde konusundaki bazı kavramların anlaşılma düzeyleri ile kavram yanılgılarının belirlenmesi ve bazı değişkenler açısından incelenmesi. Kastamonu Eğitim Dergisi, 15(1), 199-210.

Laçin-Şimşek, C., Öztuna-Kaplan, A., Çorapçıgil, A. ve Mısır, M. E. (2018). Fen bilgisi öğretmenliği 3. sınıf öğrencilerinin basınç-kaynama noktası ilişkisine yönelik düşünceleri: bir tga uygulaması. Kastamonu Eğitim Dergisi, 26(5), 1679-1690.

MEB [Milli Eğitim Bakanlığ1], (2018). Fen bilimleri dersi ögretim programı (İlkokul ve Ortaokul 3, 4, 5, 6, 7, ve 8. Sinıflar). Ankara.

National Research Council. [NRC] (1996). National Science Education Standards, Washington, DC: National Academic Press.

Osborne, R. J. \& Cosgrove, M. M. (1983). Children's conceptions of the changes of state of water. Journal of research in Science Teaching, 20(9), 825-838.

Prain, V., Tytler, R. \& Peterson, S. (2009). Multiple representation in learning about evaporation. International Journal of Science Education, 31(6), 787-808.

Ralph, M., Sexton C., Wagner, K. \& Gerlovich, J. (1998). Science for All Children: Methods for Constructing Understanding. Massachusetts: Allyn and Bacon Company.

Sherman, T. M. \& Kurshan, B. L. (2005). Constructing Learning: Using technology to support teaching for understanding. Learning \& Leading with Technology, 32(5), 10-39.

Stephen, K. (1988). Heat transfer in condensation and boling. New York: Springer-Verlag.

Turner, G. A. (1972). Heat and concentration waves. New York: Academic Press. 
Tytler, R. (2000). A comparison of Year 1 and Year 6 students' conceptions of evaporation and condensation: Dimensions of conceptual progression. International Journal of Science Education, 22(5), 447-467.

Yıldırım, A. ve Şimşek, H. (2018). Sosyal bilimlerde nitel araştırma yöntemleri. Ankara: Seçkin Yayıncılık.

\section{Summary \\ Statement of Problem}

With the rapid development of science and technology, it is aimed to raise science literate individuals who know how to reach the right information, question, think critically, and have skills such as decision-making, creativity and innovation (AAAS, 2015; MEB, 2018). In line with this goal, the science teaching program focused on the need to teach concepts based on a constructivist approach. In concept learning, students make connections between previous concepts and new concepts by using the concepts they have learned before. With the wrong establishment of these ties, it is encountered with the wrong learning of the subjects and the decrease in the quality of the learning. It is very important for students to learn correctly about the concepts at an early age, to relate to their future learning and to gain successful learning. (Bozkurt and Çakır, 2016).

There are many studies in science education regarding the learning of concepts, which is one of the most important steps of science education, misconceptions, the reasons for these mistakes and how to prevent them. It is stated that students have difficulties in understanding these concepts at an early age, since there are many misconceptions especially about the substance, and therefore, they may experience serious comprehensive problems in other subjects in the future. At this point, examining the conceptual understanding levels of teachers and teacher candidates is important for students' understanding of these concepts. From this point of view, the level of science teachers' views on concepts in the pre-service period was also a matter of curiosity and it was aimed to determine the opinions of science teacher candidates about condensation and concentration concepts. At this point, limited number of studies are encountered in the literature regarding the discrimination of these concepts. It is thought that, in order to ensure correct learning of these concepts by students, it is thought that science teacher candidates will shed light on other studies in terms of determining whether there are misconceptions of pre-service teachers and how they can be eliminated, if any. 


\section{Method}

The case study method was used to examine the opinions of science teacher candidates about condensation and concentration concepts in depth (Yıldırım and Şimşek, 2018). The study was carried out with a total of 42 science teacher candidates (37 female and 5 male) studying in the "Science Teaching" program in a state university in the Black Sea Region in the fall semester of the 2020-2021 academic year. The data of the research were collected within the scope of Physics-III course. In this study, an open-ended questionnaire was preferred as a data collection method to determine the opinions of science teacher candidates about condensation and concentration concepts. The open-ended questionnaire was sent to the e-mail addresses of the science teacher candidates and they were asked to fill in and send. Descriptive analysis was used in the analysis of the data obtained from the study.

\section{Findings}

When Table 3 is examined, it is seen that the majority of the answers given by science teacher candidates about what the concept of condensation is at the quality of "Scientifically Partially Acceptable". According to the answers they gave, it is seen that some of the teacher candidates gave "Scientifically Acceptable" answers. It is seen that they gave "Scientifically Unacceptable” answers to a lesser extent.

When Table 4 is examined, it is seen that most of the answers given by science teacher candidates about the concept of concentration are "Scientifically Unacceptable”. According to the answers they gave, it is seen that some of the science teacher candidates had "Scientifically Partially Acceptable” views. It is seen that they gave "Scientifically Acceptable” answers to a lesser extent.

When Table 5 is examined, it is seen that most of the examples given by science teacher candidates regarding the concepts of condensation and concentration are in the form of "Steam formation in glass or mirror”. At a close percentage, science teacher candidates responded as "Weather events are examples of condensation (such as frost, hail, rain, snow, cloud, fog, dew)".

When Table 6 is examined, it is seen that most of the answers given by the science teacher candidates regarding the differences in condensation and concentration are "Scientifically Partially Acceptable". According to the answers they gave, it is seen that some of the pre-service teachers had "Scientifically Acceptable" views. To a lesser extent, it is seen that they give "Scientifically Unacceptable" answers and leave it blank. 
When Table 7 is examined, it is seen that most of the responses given by science teacher candidates about the similarities of condensation and concentration are grouped under the category of "State Change" and explanations are made about the state change. It is seen that the answers given under the category of "State Change" are mostly as "Condensation and concentration are actually the same event”. According to the answers they gave, it was seen that some of the teacher candidates tried to explain the similarities of condensation and concentration based on the relationship between heat and temperature. These views are also gathered under the category of "Heat-Temperature”. It was seen that only one science teacher candidate tried to explain by establishing a relationship with the concept of density. The views of the teacher candidate on this were gathered under the category of "Intensity".

\section{Discussion and Conclusion}

Science teacher candidates have opinions about the concept of condensation that can be considered partially scientific level. Condensation, evaporation, melting, freezing and sublimation are conceptual expressions given to the change of state of materials. Each of them refers to a special case of the change of state. In fact, these concepts are the names given to the events that takes place in the process of state change. Despite this, it is seen that some of the students in the work group have misconceptions and they use the concept of condensation and concentration interchangeably. Indeed, the condensed gases become concrete when they pass into liquid form, that is, their density increases. The amount of substance per unit volume increases. From this point of view, it may seem correct. However, condensation does not occur only during the process of change. For example, when the temperature of the object decreases (except in special cases "the state of water on both sides of $+40 C$ ") the object become concrete. When evaluated from this point, the students hardly touched on this situation. As a result of their studies, Osborne and Cosgrove (1983) determined that students have a superficial knowledge of concepts such as evaporation, condensation, and boiling, and they also have some unscientific views.

In addition to explaining the concept of concentration as a state change, they think that the concepts of condensation and concentration explain the same case. It was determined that very few teacher candidates regarding the concept of concentration thought that it was related to intergranular space, increased particle frequency or density at a level that could be scientifically accepted. Science teacher candidates especially have misconceptions about the concept of concentration and use the concept of concentration instead of the concept of 
condensation. The existing problem here does not arise from experiencing a concentration process in the condensation action. It stems from the perspective of teacher candidates that the concentration is completed by this process. However, the condensed matter continues to be become concentrated as its temperature decreases. Therefore, this transition process has been named with a new concept. A teacher candidate who cannot perceive this conceptual depth cannot fully solve this physical event in his own mind and may carry this delusion to his students. Similarly, Coştu (2002) found that students had difficulties in understanding the concepts of concentration, evaporation and boiling as a result of his study.

Science teacher candidates generally gave examples of condensation based on weather events and steam formation from daily life. This may be due to the fact that the effects of concentration other than condensation cannot be easily and directly observed. It is proof that science teacher candidates cannot make a clear distinction between the concept of condensation and concentration. In addition, the fact that there are too many examples of condensation in the textbooks may have caused them to be presented as concentration examples. Similarly, Canpolat, Ateş, and Ayyıldız (2019) found that science teacher candidates were inadequate in transferring Chemistry subjects to daily life, such as changing the state, and had misconceptions.

Science teacher candidates explain the similarities of condensation and concentration with expressions about the state change. Teacher candidates think that condensation and concentration are the same events. Only one teacher candidate thinks that the concept of concentration is related to the frequency of particles, not just a state change. Similarly, Gökulu (2015) found that classroom teacher candidates had misconceptions about the concepts of heattemperature and state change.

As a result of the analysis of the answers given by the science teacher candidates, it was determined that they had misconceptions. Very few science teacher candidates can differentiate between condensation and concentration concepts, albeit partially. However, the majority of science teacher candidates see the concept of condensation and concentration as the same events and substitute the concepts for each other. This may be due to the fact that the concepts of condensation and concentration are used in the same sense in the science textbook and the science curriculum (MEB, 2018). Especially in many sites on the internet, the concept of condensation and concentration is used interchangeably, even it appears as a concept of concentration rather than condensation. Technology, which is one of the most important parts of our lives with its rapid development, is one of the sources we apply to obtain information at 
YYÜ Eğitim Fakültesi Dergisi (YYU Journal of Education Faculty), 2021;18(2)56-80, http://efdergi.yyu.edu.tr,

any time. In this respect, it can be thought that teacher candidates may have reached such misinformation on any internet site without knowing how to reach correct information by staying away from being a science literate individual, which is the general purpose of science education today. In addition to these, it is seen that the concepts of condensation and concentration are used interchangeably when translating from foreign sources. It can be thought that this situation may also be effective. 